OPEN ACCESS

Edited by:

Toshi Nagata,

The University of Tokyo, Japan

Reviewed by:

Sylvie Gaudron,

Sorbonne Université, France

Chiara Romano,

Center for Advanced Studies

of Blanes (CSIC), Spain

Onishi Yuji,

Kyoto University, Japan

${ }^{*}$ Correspondence:

Janet R. Voight

jvoight@fieldmuseum.org

Specialty section:

This article was submitted to

Marine Biogeochemistry,

a section of the journal

Frontiers in Marine Science

Received: 26 July 2019

Accepted: 27 January 2020

Published: 14 February 2020

Citation:

Voight JR, Cooper JC and Lee RW (2020) Stable Isotopic

Evidence of Mixotrophy

in Xylophagaids, Deep-Sea

Wood-Boring Bivalves.

Front. Mar. Sci. 7:50

doi: 10.3389/fmars.2020.00050

\section{Stable Isotopic Evidence of Mixotrophy in Xylophagaids, Deep-Sea Wood-Boring Bivalves}

\author{
Janet R. Voight ${ }^{1 *}$, Jacob C. Cooper ${ }^{1,2}$ and Raymond W. Lee ${ }^{3}$ \\ ${ }^{1}$ Negaunee Integrative Research Center, Field Museum of Natural History, Chicago, IL, United States, ${ }^{2}$ Committee on \\ Evolutionary Biology, The University of Chicago, Chicago, IL, United States, ${ }^{3}$ School of Biological Sciences, Washington \\ State University, Pullman, WA, United States
}

Deep-sea wood-boring xylophagaid bivalves are thought to ingest only wood and to use nitrogen fixed by their symbiotic microbes. Reconsidering this assumption, we tested whether $\delta^{13} \mathrm{C}$ and $\delta^{15} \mathrm{~N}$ isotopic values of ten species in four xylophagaid genera collected between $18 \mathrm{~m}$ and $4626 \mathrm{~m}$ depth suggest that some may use different trophic strategies. Isotopic signatures of six species were entirely consistent with predicted xylophagy, but four species, three members of the Xylophaga dorsalis clade and Abditoconus heterosiphon, had $\delta^{15} \mathrm{~N}$ signatures over $3.7 \%$, significantly higher than the value predicted for nitrogen fixed by bacteria. These species may supplement freshly fixed nitrogen with an alternate source, such as particulate organic material. Although the animals' reduced palps and the lack of microbes in the gut of laboratorymaintained specimens were cited as arguing against filter feeding, the animals may filter feed opportunistically. A. heterosiphon was unique in having $\delta^{13} \mathrm{C}$ signatures more negative than the wood into which they bored, inconsistent with cellulose consumption, and $\delta^{15} \mathrm{~N}$ values higher than predicted for nitrogen fixed by bacteria. We suggest that greater trophic diversity may exist among xylophagaids than has been expected. Ecological studies of wood-fall communities cannot assume that the entire community is sustained only by wood-bound energy. We attribute variation in $\delta^{13} \mathrm{C}$ signatures among 42 specimens of $X$. s.l. zierenbergi from six collections, five at the same depth, to variation in the type of wood bored. Investigators beginning food web studies should sample xylophagaids and wood itself; if the deployment is large, repeated samples of the wood, closely matched to xylophagaids, may be necessarily to fully define the substrate's stable isotopic signal.

Keywords: carbon isotope, nitrogen isotope, Xylophaga, Abditoconus, Xyloredo

\section{INTRODUCTION}

Wood-boring bivalves of the Xylophagaidae are thought to bore into, ingest and digest sunken wood (Distel and Roberts, 1997); in doing so they are thought to sustain diverse communities associated with wood that has sunken to the deep-sea floor (Turner, 1973). The importance of the bivalves in making the wood's energy and nutrients accessible to other animals has lately been questioned; bacteria may play a larger role than has been assumed (e.g., Kalenitchenko et al., 2018). 
This may be symptomatic of how little we know about xylophagaids; the composition of their diet has been poorly documented, but wood is widely accepted to be their main food source.

Anatomy has contributed to the belief that xylophagaids are strict xylophages. Palp size may predict filter feeding ability in teredinids (Saraswathy and Nair, 1971), the sister taxon of the xylophagaids (Distel et al., 2011). Xylophaga dorsalis has reduced palps and gills that lack strong sorting mechanisms (Purchon, 1941), features seemingly indicative of reduced filter feeding ability. However, xylophagaids that bored into the gutta-percha cover of transatlantic cables (Web, 1900) would have had to filter feed (Purchon, 1941), as would those that bored into plastics and vinyl (Muraoka, 1967). Those that were recovered from plastics were, however, half the size of those recovered from wood deployed on the same rack at $722 \mathrm{~m}$ for 13.4 months at about $5^{\circ} \mathrm{C}$ (Muraoka, 1967). These data suggest that, while possible, life without wood is less than ideal. Ansel and Nair (1969) contended, without citing supporting data, that like their relatives the boring pholadids, xylophagaids use wood for support and protection rather than for food.

More recent, data-based arguments for the animals' strict reliance on xylophagy include that individuals of Xylophaga washingtona that had been held in wood in seawater tanks had few microorganisms among the wood shavings in their gut (Distel and Roberts, 1997). The gills of the two xylophagaid species ( $X$. washingtona and Xylophaga s.l. atlantica) examined supported dense endosymbiotic bacteria, thought to help digest wood as they do in teredinids (Sabbadin et al., 2018). Teredinids appear able to survive by xylophagy, but studies using radiolabeled substrates and $\delta^{13} \mathrm{C}$ and $\delta^{15} \mathrm{~N}$ isotopic analyses find some teredinids, e.g., Lyrodus pedicellatus, Teredo navalis, Bankia carinata, filter feed at least opportunistically (Pechenik et al., 1979; Gallager et al., 1981; Paalvast and van der Velde, 2013; Charles et al., 2018). Karande et al. (1968), cited by Pechenik et al. (1979) stated that T. fucifera required phytoplankton to grow and reproduce.

Of five studies of xylophagaid $\delta^{13} \mathrm{C}$ and $\delta^{15} \mathrm{~N}$ stable isotopic signatures (Nishimoto et al., 2009; Bernardino et al., 2010; Yamanaka et al., 2015; Gaudron et al., 2016; Zapata-Hernández et al., 2016), only Gaudron et al. (2016) postulated xylophagaid filter feeding. Dwarf males of Xylophaga s.l. atlantica removed from wood that had been deployed at $2279 \mathrm{~m}$ depth near hydrothermal vents on the Mid-Atlantic Ridge had enriched $\delta^{13} \mathrm{C}$ and $\delta^{15} \mathrm{~N}$ isotopic values. In this dense population, dwarf males were concluded to filter feed on fecal matter and other by-products of large, autonomously boring females.

In terms of $\delta^{13} \mathrm{C}$ isotopic values, strictly xylophagous xylophagaids are predicted to be $1-2 \%$ enriched, that is more positive, than the wood they ate, and that the fecal chimneys of members of the $X$. dorsalis clade would be depleted, or more negative than wood. Because the bivalves digest cellulose (Purchon, 1941; Nishimoto et al., 2009), their fecal chimneys would be composed mainly of lignin. The $\delta^{13} \mathrm{C}$ signature of cellulose is enriched relative to that of lignin (Loader et al., 2003). If they ingested sulfide-oxidizing bacteria, their $\delta^{13} \mathrm{C}$ isotopic values may be depleted relative to the wood. Wood, however, is less than ideal for stable isotopic studies. Even within an individual tree, wood can have a surprisingly large range of $\delta^{13} \mathrm{C}$ signatures (e.g., Leavitt and Long, 1986; Schleser et al., 2015). Weather, age, heartwood versus sapwood, water stress, even sunlight exposure all reportedly affect wood's $\delta^{13} \mathrm{C}$ signature by over $2 \%$ (e.g., Bert et al., 1997; Korol et al., 1999; Loader et al., 2003; Taylor et al., 2007).

In terms of $\delta^{15} \mathrm{~N}$ isotopic values, strictly xylophagous xylophagaids are predicted to have mean $\delta^{15} \mathrm{~N}$ values from -2 to $+3 \%$. The extremely low nitrogen concentrations in wood, $0.08-0.2 \%$ (Filipiak, 2018), force xylophagous animals to get supplemental nitrogen. To do so, xylophagaids are thought to rely on bacteria symbiotic in their gills (Distel and Roberts, 1997). In addition to their physical presence, two bacterial species from the gills of $X$. dorsalis show a $95 \%$ genetic similarity to bacteria in the gills of teredinids that are known to fix nitrogen; other bacterial species that are more distantly affiliated with teredinid symbionts occur in other members of $X$. dorsalis (Fagervold et al., 2014). Stable isotopic signatures of nitrogen fixed by bacteria are between -2 and $0 \%$ (Somes et al., 2010). Ingestion of symbionts or recycling of nitrogen (Ferrier-Pagés and Leal, 2019) could expand the range of $\delta^{15} \mathrm{~N}$ values in xylophages to -2 to $+3 \%$, assuming conventional trophic enrichment of $3.4 \pm 1.1 \%$ (Minagawa and Wada, 1984). Values exceeding 3\%o suggest use of a different nitrogen source, such as Particulate Organic Material (POM).

To test whether xylophagaids rely exclusively on xylophagy and nitrogen-fixing bacteria, we apply $\delta^{13} \mathrm{C}$ and $\delta^{15} \mathrm{~N}$ stable isotopic analysis to 10 xylophagaid species from four clades collected from 18 to $4626 \mathrm{~m}$ depths. If a species $\delta^{13} \mathrm{C}$ value is $1-$ $2 \%$ enriched relative to the wood it bored and its $\delta^{15} \mathrm{~N}$ is between -2 and $3 \%$, it will be viewed as xylotrophic, the null hypothesis. Species that use POM would be revealed by enriched $\delta^{15} \mathrm{~N}$ values; species with depleted $\delta^{13} \mathrm{C}$ values compared to the wood it bored might ingest sulfide-oxidizing bacteria. We also report analyses of six collections of one species. With stable isotopic studies of xylophagaids so rare, and often with no or unreliable species identifications, we hope to provide a framework for future studies of these animals.

\section{MATERIALS AND METHODS}

\section{Specimens and Wood Analyzed}

Seventy-one specimens from ten localities deposited in Field Museum of Natural History (FMNH) collection and one specimen from TePapa National Museum of New Zealand (NMNZ) collection are the basis of this study (Table 1). Of these, 42 are members of Xylophaga s.l. zierenbergi removed from six deployments. The specimens differed in their source, whether from wood randomly encountered on the seafloor (i.e., "wild" wood), or wood experimentally deployed on or above the sediment and in their preservation histories. Fixation in formalin followed by storage in $70 \%$ ethanol or preservation and storage in $95 \%$ ethanol were the alternative means of preservation.

We must address two taxonomic issues. First, the genus Xylophaga is paraphyletic (Voight et al., 2019). The type species of 
TABLE 1 | The taxon, depth, locality, wood type, deployment duration (if applicable), preservation ( $F$, E formalin to ethanol; $95 \mathrm{E} 95 \%$ ethanol), mean tissue $\delta^{13} \mathrm{C}$ value (standard deviation) and number of specimens, mean tissue $\delta^{15} \mathrm{~N}$ value (standard deviation) and number of specimens, mean tissue $\mathrm{C} / \mathrm{N}$ ratio (standard deviation), mean wood $\delta^{13} \mathrm{C}$ value (standard deviation), mean wood $\delta^{15} \mathrm{~N}$ value (Standard deviation), wood $\mathrm{C} / \mathrm{N}$ ratio (standard deviation) and the source of these specimens.

\begin{tabular}{|c|c|c|c|c|c|c|c|c|c|c|}
\hline Taxon & Depth (m) & location & $\begin{array}{l}\text { Wood type, } \\
\text { deployment } \\
\text { duration, } \\
\text { preservation }\end{array}$ & $\begin{array}{c}\text { Mean tissue } \\
\delta^{13} \mathbf{C} \% \text { (Std } \\
\text { Dev) } n\end{array}$ & $\begin{array}{l}\text { Mean tissue } \\
\delta^{15} \mathbf{N} \% \text { (Std } \\
\text { Dev) } \mathbf{n}\end{array}$ & $\begin{array}{l}\text { C/N tissue } \\
\text { (Std. Dev) }\end{array}$ & $\begin{array}{l}\text { Wood } \delta^{13} \mathrm{C} \\
(\text { Std Dev) } n\end{array}$ & $\begin{array}{l}\text { Wood } \delta^{15} N \\
\text { (Std Dev) } n\end{array}$ & $\begin{array}{l}\text { Wood C/N } \\
\text { (Std Dev) }\end{array}$ & References \\
\hline $\begin{array}{l}\text { Xylophaga dorsalis } \\
\text { Bergen, Norway }\end{array}$ & 210 & $\begin{array}{l}60^{\circ} 28.915^{\prime} \mathrm{N} \\
5^{\circ} 25.065^{\prime} \mathrm{E}\end{array}$ & Wild 95 E & $\begin{array}{c}-21.8(0.03) \\
n=2\end{array}$ & $6.3(0.2) n=2$ & $3.7(0.1)$ & $\begin{array}{c}-28.1(0.4) \\
n=4\end{array}$ & $\begin{array}{c}-1.3(1.6) \\
n=4\end{array}$ & $28.9(13.7)$ & Unpub. \\
\hline $\begin{array}{l}\text { X. washingtona Friday } \\
\text { Harbor, WA } \\
\text { United States }\end{array}$ & 18 & $\begin{array}{l}48^{\circ} 32.732^{\prime} \mathrm{N} \\
123^{\circ} 0.78^{\prime} \mathrm{W}\end{array}$ & Wild 95 E & $\begin{array}{c}-23.2(1.0) \\
n=4\end{array}$ & $7.2(0.35) n=4$ & $4.6(1.2)$ & - & - & - & Unpub. \\
\hline $\begin{array}{l}\text { X. oregona* inactive } \\
\text { Juan de Fuca Ridge }\end{array}$ & 2211 & $\begin{array}{l}47^{\circ} 56.781^{\prime} \mathrm{N} \\
129^{\circ} 5.822^{\prime} \mathrm{W}\end{array}$ & Fir $24 \mathrm{mo} \mathrm{F}$, E & $\begin{array}{c}-22.4(0.2) \\
n=3\end{array}$ & $1.5(1.6) n=3$ & $4.3(0.03)$ & $\begin{array}{c}-24.3(0.2) \\
n=3\end{array}$ & $0.1(0.9) n=3$ & $863.9(667)$ & Voight (2007) \\
\hline $\begin{array}{l}\text { Xylophaga alexisi } \\
\text { Cape Verde Abyssal } \\
\text { Plain }\end{array}$ & 4626 & $\begin{array}{l}21^{\circ} 03.81^{\prime} \mathrm{N} \\
31^{\circ} 12.21^{\prime} \mathrm{W}\end{array}$ & $7 \mathrm{mo} \mathrm{F}, \mathrm{E}$ & $\begin{array}{c}-24.5(0.6) \\
n=4\end{array}$ & $4.4(0.8) n=4$ & $4.3(0.3)$ & $\begin{array}{c}-26.0(0.1) \\
n=2\end{array}$ & $0.2(0.7) n=2$ & $140.3(56.6)$ & $\begin{array}{l}\text { Voight and } \\
\text { Segonzac } \\
\text { (2012) }\end{array}$ \\
\hline $\begin{array}{l}\text { Xylophaga s.I. } \\
\text { microchira Cascadia } \\
\text { Basin }\end{array}$ & 2639 & $\begin{array}{l}47^{\circ} 42.637^{\prime} \mathrm{N} \\
127^{\circ} 47.625^{\prime} \mathrm{W}\end{array}$ & Fir $10 \mathrm{mo} \mathrm{F,} \mathrm{E}$ & $\begin{array}{c}-23.1(0.4) \\
n=2\end{array}$ & $-1.0(0.6) n=2$ & $3.8(0.2)$ & $\begin{array}{c}-24.6(0.1) \\
n=2\end{array}$ & $0.2(0.7) n=2$ & $239.8(158)$ & Voight (2007) \\
\hline $\begin{array}{l}\text { X. s.l. microchira } \\
\text { Cascadia Basin }\end{array}$ & 2639 & $\begin{array}{l}47^{\circ} 42.637^{\prime} \mathrm{N} \\
127^{\circ} 47.625^{\prime} \mathrm{W}\end{array}$ & Fir $10 \mathrm{mo} \mathrm{F,} \mathrm{E}$ & $\begin{array}{c}-22.9(0.28) \\
n=2\end{array}$ & $0.9(0.02) n=2$ & $3.8(0.4)$ & $\begin{array}{c}-24.6(0.1) \\
n=2\end{array}$ & $0.2(0.7) n=2$ & $239.8(158)$ & Voight (2007) \\
\hline $\begin{array}{l}\text { Xylophaga s.l. } \\
\text { muraokai* inactive Juan } \\
\text { de Fuca Ridge }\end{array}$ & 2211 & $\begin{array}{l}47^{\circ} 56.781^{\prime} \mathrm{N} \\
129^{\circ} 5.822^{\prime} \mathrm{W}\end{array}$ & Fir $24 \mathrm{mo} \mathrm{F,} \mathrm{E}$ & $\begin{array}{c}-23.1 \\
(0.04) n=2\end{array}$ & $1.3(0.3) n=2$ & $4.1(0.1)$ & $\begin{array}{c}-24.3(0.2) \\
n=3\end{array}$ & $0.1(0.9) n=3$ & $863.9(667)$ & Voight (2007) \\
\hline $\begin{array}{l}\text { X. s.l. muraokai } \\
\text { Monterey Canyon }\end{array}$ & 3100 & $\begin{array}{l}36^{\circ} 15.677^{\prime} \mathrm{N} \\
122^{\circ} 40.679^{\prime} \mathrm{W}\end{array}$ & Ginkgo 24 mo 95 E & $\begin{array}{c}-24.1(0.3) \\
n=3\end{array}$ & $1.7(0.7) n=3$ & $4.0(0.2)$ & - & - & - & $\begin{array}{l}\text { Judge and } \\
\text { Barry (2016) }\end{array}$ \\
\hline $\begin{array}{l}\text { Xylophaga s.l. } \\
\text { zierenbergi inactive } \\
\text { Juan de Fuca Ridge }\end{array}$ & 2211 & $\begin{array}{l}47^{\circ} 56.781^{\prime} \mathrm{N} \\
129^{\circ} 5.822^{\prime} \mathrm{W}\end{array}$ & Fir $24 \mathrm{mo} \mathrm{F}, \mathrm{E}$ & $\begin{array}{c}-23.0(0.2) \\
n=2\end{array}$ & $0.3(0.09) n=2$ & $4.2(0.2)$ & $\begin{array}{c}-24.3(0.2) \\
n=3\end{array}$ & $0.1(0.9) n=3$ & $863.9(667)$ & Voight (2007) \\
\hline $\begin{array}{l}\text { Xylophaga s.l. } \\
\text { zierenbergi Monterey } \\
\text { Canyon }\end{array}$ & 3100 & $\begin{array}{l}36^{\circ} 15.677^{\prime} \mathrm{N} \\
122^{\circ} 40.679^{\prime} \mathrm{W}\end{array}$ & Various $24 \mathrm{mo}$ & $\begin{array}{c}-24.5(1.5) \\
n=40\end{array}$ & $\begin{array}{c}-0.1(1.1) \\
n=40\end{array}$ & $3.9(0.29)$ & - & - & - & $\begin{array}{l}\text { Judge and } \\
\text { Barry (2016) }\end{array}$ \\
\hline $\begin{array}{l}\text { Abditoconus } \\
\text { heterosiphon Cascadia } \\
\text { Basin }\end{array}$ & 2658 & $\begin{array}{l}47^{\circ} 45.755^{\prime} \mathrm{N} \\
127^{\circ} 45.441^{\prime} \mathrm{W}\end{array}$ & Fir $10 \mathrm{mo} \mathrm{F,} \mathrm{E}$ & $\begin{array}{c}-25.3(0.2) \\
n=4\end{array}$ & $3.7(0.3) n=4$ & $5.7(0.2)$ & $-23.9(n=1)$ & $1.1 n=1$ & 263.4 & Voight (2007) \\
\hline $\begin{array}{l}\text { Xylopholas crooki } \\
\text { Monterey Canyon }\end{array}$ & $\begin{array}{l}3,000- \\
3,150\end{array}$ & $\begin{array}{l}36^{\circ} 29.962^{\prime} \text { to } \\
36^{\circ} 27.973^{\prime} \mathrm{N} \\
122^{\circ} 38.313^{\prime} \text { to } \\
122^{\circ} 36.7^{\prime} \mathrm{W}\end{array}$ & Wild F, E & $\begin{array}{c}-25.8(1.1) \\
n=2\end{array}$ & $1.5(0.08) n=2$ & $3.9(0.2)$ & - & - & - & Voight (2016) \\
\hline $\begin{array}{l}\text { Xyloredo nooi NMNZ } \\
\text { M.084306 } \\
\text { New Zealand }\end{array}$ & $517-518$ & $\begin{array}{l}43^{\circ} 57.28^{\prime} \mathrm{S} \\
176^{\circ} 46.03^{\prime} \mathrm{E}\end{array}$ & Wild frozen $\mathrm{F}, \mathrm{E}$ & $-22.4 n=1$ & $0.8 n=1$ & 5.2 & - & - & & $\begin{array}{l}\text { Voight et al. } \\
\text { (2019) }\end{array}$ \\
\hline
\end{tabular}

Species in the Xylophaga dorsalis clade in bold. * Indicates specimens of the three species removed from the same piece of wood. Specimens of $X$. alexisi from wood were suspended at least $50 \mathrm{~cm}$ above the sediment; those of X. s.I. zierenbergi from Judge and Barry (2016) are pooled from 5 deployments, including wood of pine, spice bush, oak, ginkgo and island ironwood (Figure 2). - indicates not measured. 
the genus, $X$. dorsalis, forms a clade with several species included here ( $X$. washingtona, $X$. oregona, $X$. alexisi). The other species named in the genus do not share a recent common ancestor with the name-bearing clade. To highlight their independent origin, despite the shared genus name, we apply "s.l." to their names. Second, when citing literature reports, we used the species names assigned in the original paper, except for Zapata-Hernández et al. (2016). They applied the name of the North Atlantic species, $X$. dorsalis, to their Chilean specimens; we use instead the name $X$. globosa, erected for a species from Valparaiso, Chile, about $8^{\circ}$ north of the collection site.

Where available, the stable isotopic values of the wood into which the animals bored were determined. Wood's very low nitrogen concentration, roughly $0.1 \%$ that in insect bodies (Filipiak and Weiner, 2014), not only forces xylophages to find an alternate nitrogen source, it made accurately determining its $\delta^{15} \mathrm{~N}$ signature extremely difficult in our laboratory. The nitrogen values we report from wood must be considered with caution. POM from our collection localities are not available. Globally, average deep-sea heterotrophic animals have isotopic values ranging from $10-13 \%$ for $\delta^{15} \mathrm{~N}$ and -17 to $-21 \%$ for $\delta^{13} \mathrm{C}$, depending on latitude (reviewed in Parzanini et al., 2019). POM data from the literature show elevated values compared with nitrogen fixed by bacteria. Examples are: tropical Atlantic (POM $300 \mathrm{~m}$ depth 6-8\%, Montoya et al., 2002), North Sea and Coastal Norway (benthic POM average 6\%, Silberberger et al., 2019), Northeast Pacific (surface POM average 8\%, Altabet et al., 1999).

\section{Specimen Preparation}

Wood, bivalves and fecal chimneys were sampled with a sterile scalpel; the samples were air-dried or placed in 95\% ethanol then air-dried. Samples (0.3-0.7 mg dry weight) were rinsed in distilled water, dried, then packaged in tin capsules for mass spectrometry, and analyzed using a Costech (Valencia, CA, United States) elemental analyzer interfaced with a continuous flow Micromass Isoprime isotope ratio mass spectrometer (EA-IRMS) for ${ }^{13} \mathrm{C} /{ }^{12} \mathrm{C}$ and ${ }^{15} \mathrm{~N} /{ }^{14} \mathrm{~N}$ ratios. Measurements are reported in $\delta$ notation [per mil (\%o)] and ovalbumin was used as a routine standard. Precision for $\delta^{13} \mathrm{C}$ and $\delta^{15} \mathrm{~N}$ was $\pm 0.2 \%$ and $\pm 0.4 \%$ (S.D. of 10 replicate standards), respectively.

We analyzed the siphon, gills, mantle and cecum of specimens of $X$. dorsalis individually to test for organ-specific biases. The wood-filled cecum had a $\delta^{13} \mathrm{C}$ isotopic value reflecting its contents, being $2 \%$ depleted compared to the muscle and gills which at $-21.7 \%$ and $-22.0 \%$ were indistinguishable given our precision. Gills had the lowest $\delta^{15} \mathrm{~N}$ value at $4.3 \%$, the cecum was intermediate at $5.1 \%$ and the muscle was $6.1 \%$. Complete data are reported in Supplementary Table S1. We opted to use the siphons for the remaining analyses due to their ease of accessibility and assumed comparability.

\section{Data Analyses}

We compared the mean $\delta^{13} \mathrm{C}$ isotopic signatures of seven bivalve species to those of subsamples of the wood into which they had bored; wood samples were lacking for the other taxa. For $X$. dorsalis and $X$. oregona, we also compared the $\delta^{13} \mathrm{C}$ and $\delta^{15} \mathrm{~N}$ isotopic signatures of the chimneys to those of tissue and wood.
To examine variation with depth, we plotted the mean $\delta^{15} \mathrm{~N}$ values of each species versus the species' collection depth, pooling the five Monterey Canyon collections of X. s.l. zierenbergi. We calculated the correlation coefficient in Excel@, both with and without the relatively shallow species.

Small within-species sample sizes limited the ability of statistical tests to assess the significance of differences. We calculated $95 \%$ confidence intervals of the mean nitrogen isotopic values of each species in Excel@, after pooling species from multiple sites. Resultant intervals that did not overlap are thus significantly different at $p<0.05$ (Zar, 1999).

We compared the $\delta^{13} \mathrm{C}$ isotopic values and the $\delta^{15} \mathrm{~N}$ isotopic values of our chemically preserved specimens to isotopic values from literature accounts that were based on frozen tissues, using the rank sum test calculated by hand.

Because multiple variables impact each sample, we performed multiple tests in R 3.6.1 ( $\mathrm{R}$ Core Team, 2019), as described here. Using clade, depth, $\delta^{13} \mathrm{C}$, wood type, taxon, and preservation method, we assessed variable importance for determining $\delta^{15} \mathrm{~N}$ using Random Forests in the package "ranger" (Wright and Ziegler, 2017), manipulating our data using the packages "data.table" (Dowle and Srinivasan, 2019) and "tidyverse" (Wickham, 2017) with reference to the Random Forest pipeline of Johnston et al. (2019). Data were visualized using "ggplot2" (Wickham, 2016). To assure that phylogeny was not overly biasing our data, we compared the nitrogen isotopic values for species that were included in a phylogenetic analysis (Voight et al., 2019) using a phylogenetically corrected ANOVA in the R package "phytools" (Revell, 2012). The phylogenetic tree was pruned to include only species represented in the isotopic analysis; each species then had one tip randomly selected to provide a phylogenetic distance for the test. Lastly, non-parametric Kruskal-Wallis tests were performed using the $\mathrm{R}$ function "kruskal.test" to determine significant differences between different variable combinations. Notably, we used this to assess how chemical preservation affected the stable isotopic signatures independent of species membership. Complete code for the analyses is presented in Supplementary Information.

\section{RESULTS}

The $\delta^{13} \mathrm{C}$ values for the 72 individual xylophagaids analyzed ranged from -26.6 to $-21.5 \%$; their $\delta^{15} \mathrm{~N}$ values ranged from -2.3 to $7.7 \%$ (Figure 1 and Table 1). Most individuals and species analyzed had $\delta^{13} \mathrm{C}$ values enriched 1.2 to $1.7 \%$ over the wood into which they bored (Table 1); their $\delta^{15} \mathrm{~N}$ isotopic values were generally between -2 and $2 \%$ (Figure 1 and Table 1). Only in Abditoconus heterosiphon were $\delta^{13} \mathrm{C}$ values depleted relative to the wood they bored, being $1.4 \%$ more negative. Three members of the $X$. dorsalis clade (X. washingtona, $X$. dorsalis, $X$. alexisi) and $A$. heterosiphon had both mean $\delta^{15} \mathrm{~N}$ values (Table 1 ) and $95 \%$ confidence intervals $>3.0$ (Table 2 ); they thus significantly exceeded the value predicted for freshly fixed nitrogen. The confidence intervals of $X$. dorsalis and $X$. washingtona did not overlap those of any other species (Table 2); their $\delta^{15} \mathrm{~N}$ values are 


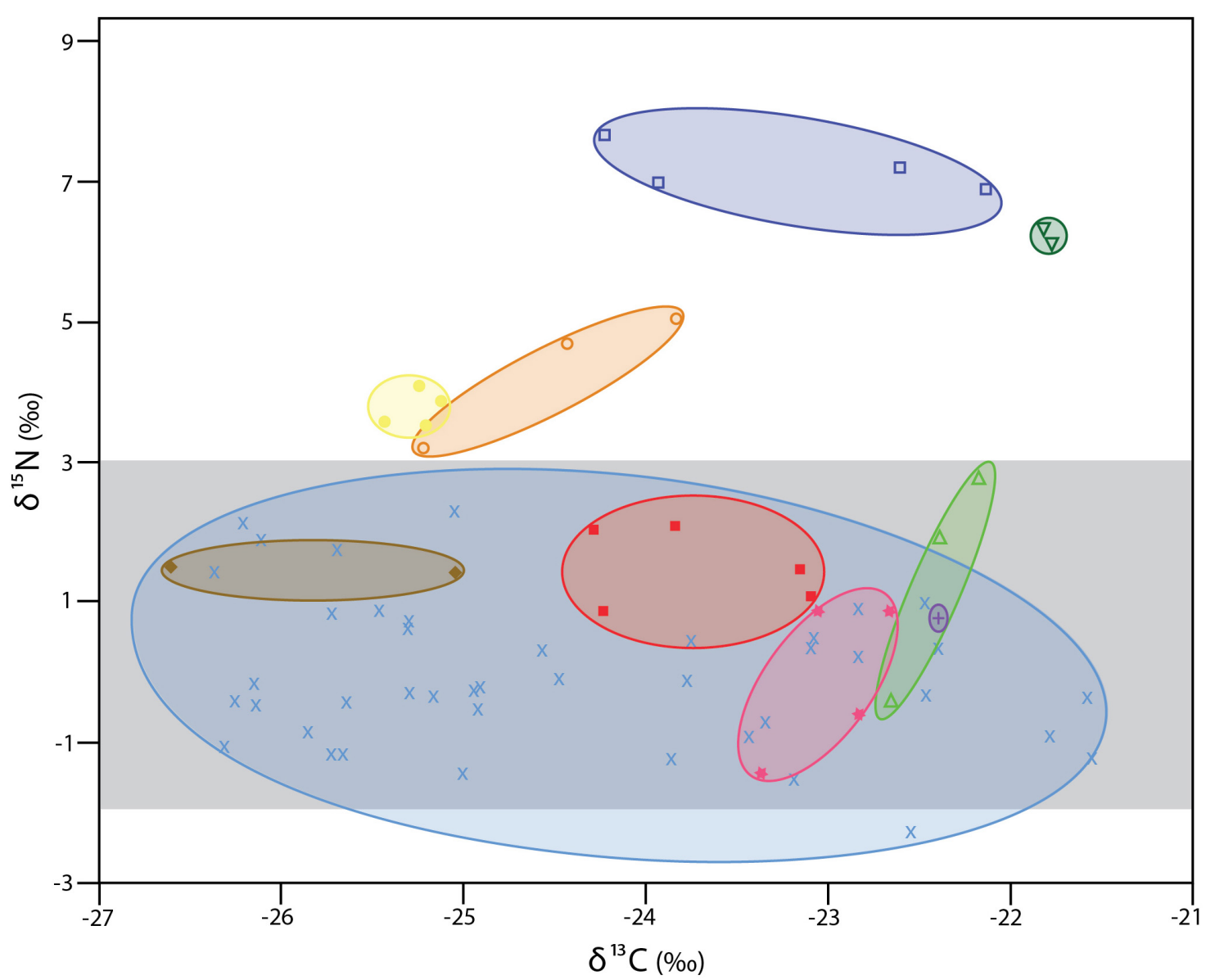

FIGURE $1 \mid \delta^{13} \mathrm{C}$ and $\delta^{15} \mathrm{~N}$ values for specimens analyzed here. Ovals unite species. All members of the $X$. dorsalis clade are represented by open symbols. Dark blue open squares $X$. washingtona; dark green open, upside-down triangles $X$. dorsalis; orange open circles $X$. alexisi; green open triangles $X$. oregona. Yellow solid circles A. heterosiphon; brown solid diamonds Xylopholas crooki; red solid squares Xylophaga s.I. muraokai; pink solid stars Xylophaga s.I. microchira; purple plus sign Xyloredo nooi; blue crosses Xylophaga s.l. zierenbergi from six pooled collections (for details see Table 1). The area highlighted in light gray is that consistent with nitrogen fixed by bacteria $(-2$ to +3$)$.

thus significantly enriched $(p<0.05)$ relative to those of every other taxon we analyzed.

Our ANOVAs failed to find any significant differences with respect to $\delta^{13} \mathrm{C}$ and $\delta^{15} \mathrm{~N}$ after phylogeny was taken into account. Different iterations result in different $p$ values, but we found these values to be ca. $p \approx 0.3$ and $p \approx 0.2$, respectively.

\section{Preservation Artifact?}

Differences in isotopic values among species do not appear to be due to preservation. $X$. dorsalis and $X$. washingtona were preserved in $95 \%$ ethanol, as were all members of $X$. s.l. zierenbergi from Monterey Canyon (Figure 1). Xylophaga alexisi and A. heterosiphon, the other species with elevated $\delta^{15} \mathrm{~N}$ values, were fixed in formalin and were stored in $70 \%$ ethanol, as were the Endeavour specimens of X. s.l. zierenbergi, X. s.l. muraokai and X. s.l. microchira with typically xylophagous $\delta^{15} \mathrm{~N}$ values (Figure 1). The results are also robust to the duration of preservation. The four outstanding species include $X$. dorsalis, collected
1 year before the analysis, and X. alexisi collected 27 years before the analysis. These are the extremes among the specimens considered.

Abditoconus heterosiphon had $\delta^{13} \mathrm{C}$ values depleted relative to the wood they bored and enriched $\delta^{15} \mathrm{~N}$ values. The specimens were collected and preserved on the same cruise, using the same chemicals, as were those of Xylophaga s.l. microchira, which had isotopic signatures entirely consistent with strict xylotrophy (Tables 1, 2). Kruskal-Wallis tests found significant effects of preservation type ( $p=0.005)$, but the formalin-fixed, ethanolstored group contained many individuals of the $X$. dorsalis clade and $A$. heterosiphon (11 of 21) while the ethanol-preserved specimens included a comparative few of these (6 of 51).

The $\delta^{13} \mathrm{C}$ values of the 40 specimens of Xylophaga s.l. zierenbergi removed from different types of wood by Judge and Barry (2016) and likely preserved in the same batch of $95 \%$ ethanol exceeded the isotopic $\delta^{13} \mathrm{C}$ range of the other 32 specimens considered, regardless of different chemicals used to preserve the latter (Figure 1). 
TABLE 2 | Reported are the number of samples, the mean $\delta^{15} \mathrm{~N}$ value, 95\% confidence interval of the mean $(\mathrm{Cl})$ and the lower and upper $95 \%$ confidence intervals for each of the nine species represented by more than one specimen treated here; specimens of $X$. s.I. zierenbergi, X. s.I. muraokai and X. s.I. microchira from two areas were pooled.

\begin{tabular}{|c|c|c|c|c|c|}
\hline Taxon & $\mathbf{n}$ & $\begin{array}{c}\text { Mean } \\
\delta^{15} \mathrm{~N} \\
\text { value }\end{array}$ & $\begin{array}{c}95 \% \\
\mathrm{Cl}\end{array}$ & $\begin{array}{c}\text { Mean } \delta^{15} \mathrm{~N} \\
\text { value minus } \\
95 \% \mathrm{Cl}\end{array}$ & $\begin{array}{c}\text { Mean } \delta^{15} \mathrm{~N} \\
\text { value plus } \\
95 \% \mathrm{Cl}\end{array}$ \\
\hline $\begin{array}{l}\text { Xylophaga } \\
\text { washingtona }\end{array}$ & 4 & 7.2 & 0.56 & 6.64 & 7.76 \\
\hline $\begin{array}{l}\text { Xylophaga } \\
\text { dorsalis }\end{array}$ & 2 & 6.3 & 1.8 & 4.5 & 8.1 \\
\hline $\begin{array}{l}\text { Abditoconus } \\
\text { heterosiphon }\end{array}$ & 4 & 3.7 & 0.48 & 3.2 & 4.2 \\
\hline $\begin{array}{l}\text { Xylophaga } \\
\text { alexisi }\end{array}$ & 4 & 4.4 & 1.27 & 3.1 & 5.7 \\
\hline $\begin{array}{l}\text { Xylophaga s.l. } \\
\text { muraokai }\end{array}$ & 5 & 1.5 & 0.68 & 0.82 & 2.2 \\
\hline $\begin{array}{l}\text { Xylopholas } \\
\text { crooki }\end{array}$ & 2 & 1.5 & 0.72 & 0.8 & 2.2 \\
\hline $\begin{array}{l}\text { Xylophaga s.l. } \\
\text { zierenbergi }\end{array}$ & 42 & -0.035 & 0.32 & -0.36 & 0.29 \\
\hline $\begin{array}{l}\text { Xylophaga s.l. } \\
\text { microchira }\end{array}$ & 4 & -0.072 & 1.83 & -1.9 & 1.8 \\
\hline $\begin{array}{l}\text { Xylophaga } \\
\text { oregona }\end{array}$ & 3 & 1.5 & 4.0 & -2.5 & 5.5 \\
\hline
\end{tabular}

Bolded are significantly elevated $\delta^{15} \mathrm{~N}$ values with a lower $\mathrm{Cl}>3$.

The specimens analyzed that were preserved by different chemical treatments (Table 1) did not significantly differ in either $\delta^{13} \mathrm{C}$ or $\delta^{15} \mathrm{~N}$ isotopic values from specimens reported in the literature that had been frozen (noted in Table 3 ) prior to isotopic analyses (for $\delta^{13} \mathrm{C}$ isotopic values $W=0.514 ; p>0.05$; for $\delta^{15} \mathrm{~N}$ isotopic values $W=0.543 ; p>0.05)$.

Our Random Forest analyses found the most important variable associated with $\delta^{15} \mathrm{~N}$ signatures was clade membership, followed by depth, $\delta^{13} \mathrm{C}$ value, wood type, taxon and lastly preservation. Given that preservation type covaried strongly with species, evidence for preservation type affecting our results appears to be lacking. Our phylogenetically corrected ANOVAs of Xyloredo nooi, Xylophaga dorsalis, X. washingtona, X. s.l. zierenbergi, X. s.l. muraokai, A. heterosiphon, and Xylopholas crooki failed to find significant differences in $\delta^{15} \mathrm{~N}$ or $\delta^{13} \mathrm{C}$ values between clades after phylogenetic correction in multiple repeated randomized samplings of the phylogenetic tree. These groups did not statistically differ from one another after accounting for shared evolutionary history.

\section{Xylophaga dorsalis Clade}

In addition to the three members of the $X$. dorsalis clade with significantly elevated $\delta^{15} \mathrm{~N}$ values (Table 2 ), the fourth member of the clade considered, $X$. oregona, had a mean $\delta^{15} \mathrm{~N}$ value of $1.5 \pm 1.6 \%$, among the highest of the remaining species considered (Table 1), with the largest standard deviations (Table 1) and much larger confidence intervals (Table 2).

Contrary to our predictions for strict xylophagy, the $\delta^{13} \mathrm{C}$ values of the fecal chimneys of $X$. dorsalis (mean $=-26.9 \pm 1.1 \%$; $n=8)$ were intermediate between those of wood $(-28.1 \pm 0.4 \% 0$ $n=5)$ and siphon tissue $(-21.8 \pm 0.03 \% ; n=2)$ (Supplementary Table S3). Consistent with our predictions, the tissues (mean $\delta^{13} \mathrm{C}-22.4 \pm 0.2 \%$; $n=3$ ) of $X$. oregona were enriched relative to the wood $(-24.3 \pm 0.2 \% ; n=3)$ and the chimneys were depleted (mean $\delta^{13} \mathrm{C}-25.5 \pm 0.6 \% 0 ; n=5$ ) (Supplementary Table S3).

\section{Relationship of Depth to Stable Nitrogen Isotopic Signature}

The species' collection depths were not significantly correlated with their mean $\delta^{15} \mathrm{~N}$ values $(r=0.394 ; n=13 ; p>0.05)$. Removing the extreme shallow-water $(<500 \quad \mathrm{~m})$ species ( $X$. dorsalis and $X$. washingtona) and recalculating did not discover a significant relationship $(r=0.467 ; n=11 ; p>0.10)$. Kruskal-Wallis tests found depth to be significantly linked to $\delta^{15} \mathrm{~N}(p<<0.05)$ when individuals rather than species means were considered.

\section{Within Species Variation}

The $\delta^{13} \mathrm{C}$ isotopic values of six collections of 42 specimens of Xylophaga s.l. zierenbergi ranged from -26.4 to $-21.5 \%$, exceeding the combined range of all other specimens considered (Figure 1). The most depleted $\delta^{13} \mathrm{C}$ isotopic values of $X$. s.l. zierenbergi were from those removed from bark-covered logs of Pinus pinea and Quercus agrifolia (mean -25.7\%0). The borers in the $P$. pinea deployment also included seven of the eleven most enriched in $\delta^{15} \mathrm{~N}$ values (mean $1.6 \pm 0.6 \%$ ) of the 42 specimens of $X$. s.l. zierenbergi. Even with these outstanding specimens, the $\delta^{15} \mathrm{~N}$ isotopic values of this species ranged from -2.3 to $2.3 \%$, within the predicted range of freshly fixed nitrogen (Supplementary Table S2). The $\delta^{13} \mathrm{C}$ values of $X$. s.l. zierenbergi from a single ginkgo log spanned $4.0 \%$ (Figure 2). The $\delta^{13} \mathrm{C}$ values of specimens from deployed spicebush sticks ranged from near -25 to $-22.5 \%$; they also showed a comparatively wide range of $\delta^{15} \mathrm{~N}$ values ( -2.25 to $\left.1.0 \% 0\right)$.

\section{DISCUSSION}

The stable isotopic signatures of six of ten xylophagaid species we considered are entirely consistent with predicted stable isotopic signatures of strict xylophages; they eat the wood that they bore and use nitrogen fixed by bacteria. The other four species (X. dorsalis, X. washingtona, X. alexisi and A. heterosiphon) have $\delta^{15} \mathrm{~N}$ values significantly enriched compared to those we predict characterize nitrogen fixed by bacteria; they are the focus of our discussion. Although supporting data are required, we offer a hypothesis of filter feeding.

\section{Clade Membership and Preservation Effects}

Members of the $X$. dorsalis clade, $X$. dorsalis, $X$. washingtona, and $X$. alexisi have mean $\delta^{15} \mathrm{~N}$ values from 4.4 to $6.5 \%$; these significantly exceed those predicted for bacterial nitrogen fixation. Comparable data for members of this clade have been reported previously: Bernardino et al. (2010) plotted three 
TABLE 3 | Literature data for $\delta^{13} \mathrm{C}$ and $\delta^{15} \mathrm{~N}$ of Xylophagaidae.

\begin{tabular}{|c|c|c|c|c|c|c|c|c|c|c|}
\hline Taxon & $\begin{array}{l}\text { Depth } \\
(\mathrm{m})\end{array}$ & Location & $\begin{array}{l}\text { Wood type, } \\
\text { Deployment } \\
\text { duration, } \\
\text { preservation }\end{array}$ & $\begin{array}{c}\text { Mean Tissue } \\
\delta^{13} \mathbf{C} \% \text { (std } \\
\text { dev) } n\end{array}$ & $\begin{array}{c}\text { Mean } \delta^{15} \mathrm{~N} \\
\% 0(\text { std dev) }\end{array}$ & $\begin{array}{l}\text { Tissue } \mathrm{C} / \mathrm{N} \\
\text { ratio }\end{array}$ & $\begin{array}{l}\text { Wood } \delta^{13} \mathrm{C} \\
\text { (std dev) n }\end{array}$ & $\begin{array}{l}\text { Wood } \delta^{15} N \\
(\text { std dev) (n) }\end{array}$ & $\begin{array}{l}\text { Wood } \\
\text { C/N }\end{array}$ & References \\
\hline Xylophaga sp. Wood A & $150-250$ & $\begin{array}{l}34^{\circ} 4.26^{\prime} \mathrm{N} \\
136^{\circ} 18.06^{\prime} \mathrm{E}\end{array}$ & $\begin{array}{l}\text { Wild wood, } \\
\text { frozen }\end{array}$ & $\begin{array}{c}-26.2(1.57) \\
n=2\end{array}$ & $4.4(0.07)$ & $\sim 7$ & $\begin{array}{c}-27.1 \\
(0.01) n=2\end{array}$ & $4.17(0.61)$ & 120 & $\begin{array}{l}\text { Nishimoto et al. } \\
\text { (2009) }\end{array}$ \\
\hline Xylophaga sp. Wood C & 150-250 & $\begin{array}{l}34^{\circ} 25.86^{\prime} \mathrm{N} \\
138^{\circ} 24.66^{\prime} \mathrm{E}\end{array}$ & $\begin{array}{l}\text { Wild wood, } \\
\text { frozen }\end{array}$ & $\begin{array}{c}-24(0.26) \\
n=7\end{array}$ & $3.8(0.18)$ & $\sim 7$ & $\begin{array}{l}-25.7 \\
n=1\end{array}$ & 1.02 & 138 & $\begin{array}{l}\text { Nishimoto et al. } \\
\text { (2009) }\end{array}$ \\
\hline Xylophaga washingtona & 1670 & $\begin{array}{l}33^{\circ} 27^{\prime} \mathrm{N} 119^{\circ} \\
22^{\prime} \mathrm{W}\end{array}$ & Fir, $5.5 \mathrm{yr}, ?$ & $\begin{array}{l}-24 n=1 \\
-22.0 n=1\end{array}$ & $\begin{array}{l}0.2 n=1 \\
5.0 n=1\end{array}$ & 0.75 & $\begin{array}{c}-24.3(0.2) \\
n=2\end{array}$ & $5.5(0.6)$ & - & $\begin{array}{l}\text { Bernardino } \\
\text { et al. (2010) }\end{array}$ \\
\hline $\begin{array}{l}\text { Xylophaga s.I. atlantica } \\
\text { }+\frac{}{9}\end{array}$ & 2279 & $\begin{array}{l}36^{\circ} 13.745^{\prime} \mathrm{N} \\
33^{\circ} 54.05^{\prime} \mathrm{W}\end{array}$ & $\begin{array}{l}\text { Pine, } 414 \text { days, } \\
\text { frozen }\end{array}$ & $\begin{array}{c}-21.7(0.3) \\
n=3\end{array}$ & $4.6(0.5)$ & $5.3(0.3)$ & $\begin{array}{c}-23.1(0.1) \\
n=3\end{array}$ & - & $\begin{array}{l}159.6 \\
(17.3)\end{array}$ & $\begin{array}{l}\text { Gaudron et al. } \\
\text { (2016) }\end{array}$ \\
\hline $\begin{array}{l}\text { Xylophaga s.l. atlantica } \\
\text { dwarf ơ } 0^{7}\end{array}$ & 2279 & $\begin{array}{l}36^{\circ} 13.745^{\prime} \mathrm{N} \\
33^{\circ} 54.05^{\prime} \mathrm{W}\end{array}$ & $\begin{array}{l}\text { Pine, } 414 \text { days, } \\
\text { frozen }\end{array}$ & $\begin{array}{l}-20.2 n=30 \\
\text { pooled }\end{array}$ & 6.4 & 3.8 & $\begin{array}{c}-23.1(0.1) \\
n=3\end{array}$ & - & $\begin{array}{l}159.6 \\
(17.3)\end{array}$ & $\begin{array}{l}\text { Gaudron et al. } \\
\text { (2016) }\end{array}$ \\
\hline Xylophaga globosa & $101-324$ & $\begin{array}{l}41^{\circ} 48^{\prime} \mathrm{S} \\
72^{\circ} 48^{\prime} \mathrm{W}\end{array}$ & Wild wood,? & $\begin{array}{c}-23.5(0.8) \\
n=7\end{array}$ & $9.0(5.1)$ & $3.6(0.4)$ & $\begin{array}{c}?-24.6 \\
(0.7) n=2\end{array}$ & $\begin{array}{c}9.2(0.3) 0.7 \\
(0.2)\end{array}$ & $\begin{array}{l}? 27.2 \\
(6.8)\end{array}$ & $\begin{array}{l}\text { Zapata- } \\
\text { Hernández } \\
\text { et al. (2016) }\end{array}$ \\
\hline Xyloredo teramachii & 276 & $\begin{array}{l}24^{\circ} 57.19^{\prime} \mathrm{N} \\
125^{\circ} 57.29^{\prime} \mathrm{E}\end{array}$ & $\begin{array}{l}\text { Zelkova serrata, } \\
13 \mathrm{mo}, \\
\text { freeze-dried }\end{array}$ & $\begin{array}{c}-27.5(0.2) \\
n=4\end{array}$ & $3.2(1.6)$ & - & $\begin{array}{c}-27.4(0.3) \\
n=3\end{array}$ & $-0.2(1.2)$ & 554.3 & $\begin{array}{l}\text { Yamanaka et al } \\
\text { (2015) }\end{array}$ \\
\hline Xyloredo teramachii & 276 & $\begin{array}{l}24^{\circ} 57.19^{\prime} \mathrm{N} \\
125^{\circ} 57.29^{\prime} \mathrm{E}\end{array}$ & $\begin{array}{l}\text { Zelkova serrata, } \\
13 \text { mo, } \\
\text { freeze-dried }\end{array}$ & $\begin{array}{c}-26.6(0.8) \\
n=3\end{array}$ & $3.8(1.1)$ & - & $\begin{array}{c}-27.3(0.3) \\
n=3\end{array}$ & $-0.3(0.4)$ & 554.3 & $\begin{array}{l}\text { Yamanaka et al } \\
\text { (2015) }\end{array}$ \\
\hline Xyloredo teramachii & 500 & $\begin{array}{l}24^{\circ} 45.00^{\prime} \mathrm{N} \\
125^{\circ} 44.99^{\prime} \mathrm{E}\end{array}$ & $\begin{array}{l}\text { Zelkova serrata, } \\
22 \text { mo, } \\
\text { freeze-dried }\end{array}$ & $\begin{array}{c}-25.8(0.8) \\
n=3\end{array}$ & $2.3(0.8)$ & - & $\begin{array}{c}-28(1.7) \\
n=3\end{array}$ & $0.8(1.6)$ & 509.1 & $\begin{array}{l}\text { Yamanaka et al. } \\
\text { (2015) }\end{array}$ \\
\hline Xyloredo teramachii & 1000 & $\begin{array}{l}24^{\circ} 35.01^{\prime} \mathrm{N} \\
125^{\circ} 45.51^{\prime} \mathrm{E}\end{array}$ & $\begin{array}{l}\text { Zelkova serrata, } \\
22 \text { mo, } \\
\text { freeze-dried }\end{array}$ & $\begin{array}{c}-25.7(1.1) \\
n=4\end{array}$ & $0.8(1.0)$ & - & $\begin{array}{c}-28.3(0.7) \\
n=3\end{array}$ & $-1.1(1.7)$ & 685.6 & $\begin{array}{l}\text { Yamanaka et al } \\
\text { (2015) }\end{array}$ \\
\hline
\end{tabular}

Reported are taxon, depth, locality, wood type, deployment duration if applicable, mean tissue $\delta^{13} \mathrm{C}$ (standard deviation) number, mean tissue $\delta^{15} \mathrm{~N}$ (standard deviation), tissue C/N ratio, mean wood $\delta^{13} \mathrm{C}$ (standard deviation) number, mean wood $\delta^{15} \mathrm{~N}$ (standard deviation) number, wood $\mathrm{C} / \mathrm{N}$ ratio and the literature reference. - indicates the data were not reported; ? indicates the reference was unclear. 


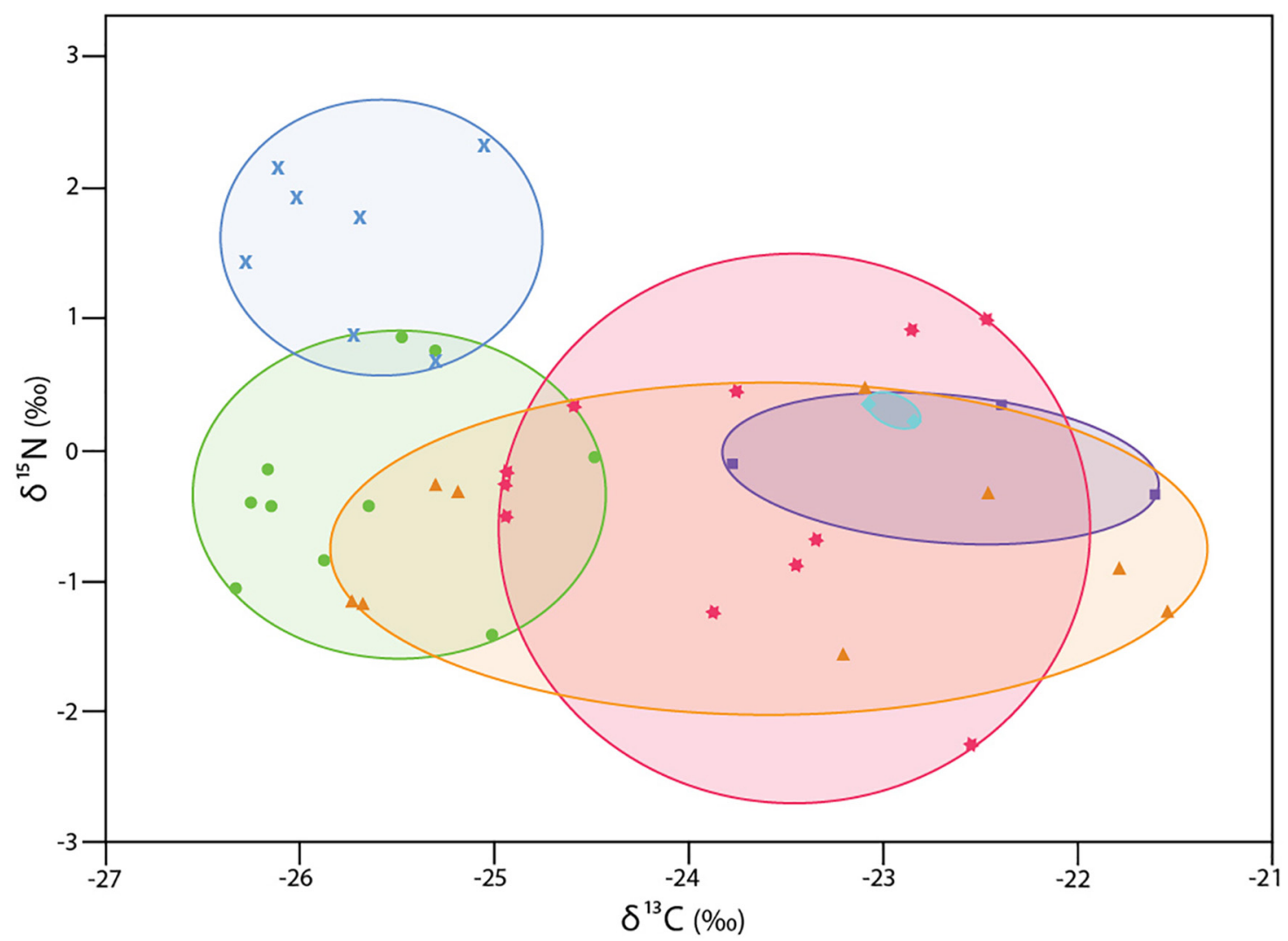

FIGURE $2 \mid \delta^{13} \mathrm{C}$ and $\delta^{15} \mathrm{~N}$ values for 42 specimens of Xylophaga s.l. zierenbergi from six deployments. wood bundles (WB) except aqua diamonds: from Douglas fir on Endeavour Segment, Juan de Fuca Ridge at 2211 m depth (Voight, 2007); all others are from deployments near Monterey Canyon at $3100 \mathrm{~m}$ depth (Judge and Barry, 2016): blue crosses bark-covered pine log (WB17); green circles bark-covered oak log (WB23); orange triangles gingko logs (WB26); pink stars spicebush sticks (WB19); purple squares island ironwood (WB32).

individuals of $X$. washingtona as having an average $\delta^{15} \mathrm{~N}$ signature near 4.9\%; Zapata-Hernández et al. (2016) reported X. globosa, assigned to this clade due to its morphology (Turner, 1955), to have $\delta^{15} \mathrm{~N}$ values of $9 \pm 5.1 \%$. These data and the fact that most of these specimens were collected from shallow, likely more productive depths suggest that these xylophagaids may filter feed. The $X$. dorsalis clade has a significantly shallower distribution than do other members of the family (Voight, 2008).

One member of the clade, Xylophaga alexisi, violates the depth generality. From $4626 \mathrm{~m}$ depth in the Cape Verde Abyssal Plain, it has a mean $\delta^{15} \mathrm{~N}$ value of $4.4 \%$, despite the predicted scarcity of plankton at the abyssal collection depths. A simultaneously deployed near-bottom sediment trap, however, documented that the deployment re-suspended abyssal sediments (Khripounoff et al., 1998); perhaps these xylophagaids fed on these particles. Deep-sea nitrogen particulates may have comparatively high $\delta^{15} \mathrm{~N}$ signatures (Sigman and Casciotti, 2001). Globally, deep-sea heterotrophic animals have average $\delta^{15} \mathrm{~N}$ isotopic values from 10 to $13 \%$ depending on latitude (reviewed in Parzanini et al., 2019). Montoya et al. (2002) found POM $\delta^{15} \mathrm{~N}$ increases rapidly to 6$8 \%$ in the first $300 \mathrm{~m}$ in the tropical Atlantic. A small amount of abyssal sediment may enrich ${ }^{15} \mathrm{~N}$ values to a greater degree than would be expected at shallow depths.
Limited behavioral data may support the hypothesis of filter feeding in the $X$. dorsalis clade. These taxa share an otherwise unique excurrent siphon that is truncated relative to the incurrent siphon. The incurrent siphon can extend over a $\mathrm{cm}$ beyond the wood (Purchon, 1941) into the water column, as in situ photos show (Bernardino et al., 2010, Figure 2b; Romano et al., 2014, Figure 2). Siphonal extension was thought to ensure access to well-oxygenated water, away from dense populations with the numerous fecal chimneys in the wood. Siphonal extension could, however, also facilitate filter feeding. As dense populations bore the wood, some individuals might secure more resources from the water column than from the remaining wood. Perhaps the extremely high variation in stable isotopic $\delta^{15} \mathrm{~N}$ signatures we document in individuals of $X$. oregona from an unusually dense population is indicative of such a scenario.

An alternate explanation for the enriched $\delta^{15} \mathrm{~N}$ signatures of the $X$. dorsalis clade is vertical transmission of a cladespecific symbiont that used another source of nitrogen. Available data, however, argue against vertical transmission of symbionts. Pyrosequencing revealed that two symbionts from three individuals of $X$. dorsalis (as sp. A) share 95\% genetic similarity to those known from shallow-water teredinids 
(Fagervold et al., 2014). This supports environmental acquisition of symbionts rather than vertical transmission.

The fourth species identified here as an outlier, A. heterosiphon, is the only species to have a mean $\delta^{13} \mathrm{C}$ value $(-25.3 \pm 0.15 \%)$ more depleted than is the wood $(-23.9 \%)$ it bored, and apparently consumed. Its mean $\delta^{15} \mathrm{~N}$ signature of $3.7 \%$ is also significantly enriched compared to predictions for nitrogen fixed by bacteria. This species has complete siphons which are covered by a periostracal cone (Voight, 2007), seemingly eliminating the possibility of filter feeding. Perhaps this species exploits wood-fall associated sulfide-oxidizing bacteria (e.g., Kalenitchenko et al., 2018). Its $\delta^{13} \mathrm{C}$ values are depleted relative to those of $X$. s.l. microchira that were collected during the same cruise from the same type of wood deployed at the same time and preserved in the same way with the same chemicals.

Different chemical preservatives minimally affect the stable isotopic signatures discussed here. The comparatively high variation in $\delta^{13} \mathrm{C}$ values in wood that is likely to be reflected in the $\delta^{13} \mathrm{C}$ values of strictly xylophagous bivalves (Figure 2 ), and the fact that stable nitrogen isotopic values are typically more robust to preservatives than are $\delta^{13} \mathrm{C}$ values (Kaehler and Pakhomov, 2001; Ogawa et al., 2001; Sarakinos et al., 2002; Syväranta et al., 2008, 2011; Rennie et al., 2012; González-Bergonzoni et al., 2015), likely contributed to this result.

\section{The Effects of Wood}

The wood substrate into which the animals bore also appears to affect their $\delta^{13} \mathrm{C}$ values. Specimens of Xylophaga zierenbergi removed from bark-covered pine and oak logs have distinctly depleted $\delta^{13} \mathrm{C}$ values compared to conspecifics from the wood of spice bush, island ironwood, and Douglas fir. Those from logs of $P$. pinea, identified by Judge and Barry (2016), also have relatively enriched $\delta^{15} \mathrm{~N}$ values. Why these seemingly anomalous values are present remains open to conjecture and may offer an attractive area for future research. The $\delta^{13} \mathrm{C}$ value of $P$. pinea reported in the literature is relatively depleted, -26.1 and $-27 \%$ (Battipaglia et al., 2010; Sarris et al., 2013), but specimens of X. s.l. zierenbergi from both pine and the oak have relatively depleted $\delta^{13} \mathrm{C}$ values. Perhaps notably, both the pine and oak logs were bark-covered; the bark may affect the wood, or its microbial community.

The $\delta^{15} \mathrm{~N}$ values of five of seven specimens from $P$. pinea are enriched relative to conspecifics, although they remain within our predicted range for nitrogen fixed by bacteria. Specimens removed from spice bush wood show more variation in the $\delta^{15} \mathrm{~N}$ values than do those from other substrates (Figure 2). Wood itself cannot be responsible for enriching the $\delta^{15} \mathrm{~N}$ values as its nitrogen content is too low to do so. Other factors such as oxygen levels possibly mediated by the bark covering could have influenced these results. Could such factors also have resulted in the enriched $\delta^{15} \mathrm{~N}$ values of the three members of the $X$. dorsalis clade? Given that the dramatically and consistently enriched $\delta^{15} \mathrm{~N}$ values of three species of that clade derive from wild wood falls and artificial deployments in the North Atlantic and the North Pacific from depths of 18 to $4626 \mathrm{~m}$, it seems unlikely but proof is lacking. In addition, the $\delta^{13} \mathrm{C}$ values of the $X$. dorsalis clade are generally not depleted, being directly comparable to most specimens of $X$. s.l. zierenbergi and to predictions for strict xylophagy.

\section{Xylophagy: A Flawed Conclusion?}

The implicit view that all xylophagaids are strict xylophages has uncertain origins. Purchon (1941) reported reduced palps in $X$. dorsalis and the poor sorting potential of their gills (Distel and Roberts, 1997). Reduced palps do characterize bivalves that host chemosynthetic bacteria on their gills (Roeselers and Newton, 2012), but gill endosymbionts do not preclude filter feeding. Bivalves of Lucinoma borealis and mussels of Bathymodiolus are among the chemosynthetic bivalves documented to feed by both means; the lucinids are estimated to obtain about half of their carbon through filter feeding (Dando et al., 1986; Page et al., 1990). Reduced palps appear to poorly predict filter feeding in wood borers, despite statements to the contrary (Saraswathy and Nair, 1971). In T. navalis, the paired dorsal palps are inconspicuous and the ventral ones are reduced to slightly raised ciliated patches (Lazier, 1924). Saraswathy and Nair (1971) cited Lazier's (1924) report but omitted his mention that the palps' function is "retained in Teredo" (p. 458), although whether they effectively controlled the plankton stream was doubtful (Lazier, 1924). Isotopic data indicate that $T$. navalis secures most of its carbon through filter feeding (Paalvast and van der Velde, 2013). The stable isotopic signatures of B. carinata, another teredinid with small palps (Saraswathy and Nair, 1971 as B. indica, synonymy following Turner, 1966), indicate that it relies entirely on xylophagy (Charles et al., 2018). The small palps of $X$. dorsalis may limit sorting, but captive individuals regularly expel pseudofeces through the incurrent siphon (JRV oight unpub data), which may indicate they exert some selection.

The scarcity of alternative food sources in the deep sea was cited by Distel and Roberts (1997) as limiting xylophagaid filter feeding. However, the species they examined had been collected at 60 and 80-100 m depth. Distel and Roberts (1997) reported few phytoplankton or microorganisms in the gut of the two species of Xylophaga they examined, but the animals had been maintained in "seawater tanks," potentially without a source of plankton, for up to 2 weeks before their examination; whether they examined the cecum, which has few microbes in teredinids, or the intestine, which hosts many more microbes in teredinids (Betcher et al., 2012), was not stated.

The nitrogen isotopic data cited as supporting the hypothesis of filter feeding can be subject to interpretation. A case in point is the elevated $\delta^{15} \mathrm{~N}$ signature of dwarf males of Xylophaga s.l. atlantica that was interpreted as evidence of filter feeding on fecal matter and by-products of boring in a dense population (Gaudron et al., 2016). An alternate explanation for these data is that they might reflect dwarf males parasitizing the autonomously boring female to which they attach. A review of parasitic interactions (Thieltges et al., 2019) found that parasites rarely exhibit a standard trophic shift of $\delta^{15} \mathrm{~N} \mathrm{3.4 \% 0.} \mathrm{The} \mathrm{trophic} \mathrm{shift}$ in $\delta^{15} \mathrm{~N}$ values seen in host-parasite interactions is often much lower, averaging $1.7 \%$; the nature of the parasitic interaction is likely to strongly impact that value. How the dwarf males access female resources remains conjectural; in this clade, dwarf males attach to the dorsal shell (Voight et al., 2019) rather than to 
the tissues of the autonomous borers as in other clades, such as Feaya dostwous (Voight, 2016). The high mean $\delta^{15} \mathrm{~N}$ values $(4.6 \pm 0.5 \%$ ) of the autonomously boring females $X$. s.l. atlantica may reflect the influence of nearby hydrothermal fluid flow (Gaudron et al., 2016).

In a study that included sulfur isotopic data of the bivalves and wood, and amino acid $\delta^{15} \mathrm{~N}$ analyses, Yamanaka et al. (2015) report xylophagy by individuals of Xyloredo teramachii in deployments made at four depths. Yamanaka et al. (2015) used compound-specific isotopic analyses and patterns observed in marine nitrogen-fixing cyanobacteria, and terrestrial plants (Chikaraishi et al., 2009) to conclude that the bivalves were entirely xylophagous. Although their standard deviations overlapped, the mean $\delta^{15} \mathrm{~N}$ values of the bivalves at each depth are significantly and negatively correlated with depth $(r=-0.972 ; n=4 ; p<0.05)$. A significant correlation would be expected if the animals were to opportunistically filter feed in shallower, more productive waters.

The intraspecific, and intra-deployment, variation in $\delta^{13} \mathrm{C}$ signatures among specimens of Xylophaga s.l. zierenbergi may warn investigators seeking to use stable isotopic analyses of xylophagaids in food web studies. The points representing $X$. s.l. zierenbergi from gingko generally form two clusters, perhaps indicative differences between the heartwood and sapwood exposed on that log (J. Judge, unpub data). The origin of each xylophagaid might strongly influence its stable isotopic signatures. Multiple xylophagaids to be analyzed should be sampled from different parts of the wood, and matched with wood samples from the same specific area, to test if intra-wood differences affect the results. Such within-wood differences are consistent with the observed $4 \% 0$ range in $\delta^{13} \mathrm{C}$ values of a single species in a single deployment.

The entrenched idea of strict xylophagy and the few comparable data available from other xylophagaids may have led to elevated stable isotopic signatures being discounted. Additional study of correctly identified taxa, collection and analysis of samples of particulate organic matter and sediment associated with the bored wood-fall are required to fully test the hypothesis that mixotrophy exists in xylophagaids. Although filter feeding may be opportunistic and not necessarily occur in every habitat or in every taxon, assuming that wood is the

\section{REFERENCES}

Altabet, M. A., Pilskaln, C., Thunell, R., Pride, C., Sigman, D., Chavez, F., et al. (1999). The nitrogen isotope biogeochemistry of sinking particles from the margin of the eastern North Pacific. Deep Sea Res. Part I 46, 655-679. doi: 10.1016/s0967-0637(98)00 084-3

Ansel, A. D., and Nair, N. B. (1969). The mechanisms of boring in Martesia striata Linne (Bivalvia: Pholadidae) and Xylophaga dorsalis Turton (Bivalvia: Xylophaginidae). Proc. R. Soc. Lond. B 174, 123-133. doi: 10.1098/rspb.1969. 0084

Battipaglia, G., Marzaioli, F., Lubritto, C., Altieri, S., Strumia, S., Cherubini, P., et al. (2010). Traffic pollution affects tree-ring width and isotopic composition sole source of energy available to wood-fall communities may be fallacious. The amount of unknown variation in the composition of wood-fall communities (McClain and Barry, 2014; Judge and Barry, 2016) argues that assumptions should be re-examined.

\section{DATA AVAILABILITY STATEMENT}

All datasets generated for this study are included in the article/Supplementary Material.

\section{AUTHOR CONTRIBUTIONS}

JV: conceptualization, funding acquisition, resources, visualization, writing original draft preparation, review, editing, and revision. JC: statistical analyses, editing, and revision. RL: conceptualization, data curation, formal analysis, investigation, project administration, resources, validation, and writing review and editing.

\section{FUNDING}

Funding was provided by the Robert A. Pritzker Center for Meteoritics and Polar Studies established by a grant from the Tawani Foundation.

\section{ACKNOWLEDGMENTS}

We thank University of Bergen Marine Station; Captain and crew of the R/V HAns BRATtstrom. J. Judge who donated specimens of $X$. s.l. zierenbergi to Field Museum; C. R. Smith and $\mathrm{K}$. Halanych provided specimens of X. washingtona; B. Marshall allowed sampling of Xyloredo nooi from his collection. Lisa Kanellos executed the plots.

\section{SUPPLEMENTARY MATERIAL}

The Supplementary Material for this article can be found online at: https://www.frontiersin.org/articles/10.3389/fmars. 2020.00050/full\#supplementary-material

of Pinus pinea. Sci. Total Environ. 408, 586-593. doi: 10.1016/j.scitotenv.2009. 09.036

Bernardino, A. F., Smith, C. R., Baco, A., Altamira, I., and Sumida, P. Y. G. (2010). Macrofaunal succession in sediments around kelp and wood falls in the deep NE Pacific and community overlap with other reducing habitats. Deep Sea Res. I 57, 708-723. doi: 10.1016/j.dsr.2010.03.004

Bert, D., Leavitt, S. W., and Dupouey, J.-L. (1997). Variations of wood $\delta 13 C$ and water-use efficiency of Abies alba during the last century. Ecology 78, 1588-1596. doi: 10.1890/0012-9658(1997)078\%5B1588:vowcaw\%5D2.0.co;2

Betcher, M. A., Fung, J. M., Han, A. W., O’Connor, R., Seronay, R., Concepcion, G. P., et al. (2012). Microbial distribution and abundance in the digestive system of five shipworm species (Bivalvia: Teredinidae). PLoS One 7:e45309. doi: 10.1371/journal.pone.0045309 
Charles, F., Sauriau, P.-G., Aubert, F., Lebreton, B., Lantoine, F., and Riera, P. (2018). Sources partitioning in the diet of the shipworm Bankia carinata (J.E. Gray, 1827): an experimental study based on stable isotopes. Mar. Environ. Res. 142, 208-213. doi: 10.1016/j.marenvres.2018.10.009

Chikaraishi, Y., Ogawa, N. O., Kashiyama, Y., Takano, Y., Suga, H., Tomitani, A., et al. (2009). Determination of aquatic food-web structure based on compoundspecific nitrogen isotopic composition of amino acids. Limnol. Oceanogr. 7 , 740-750. doi: 10.1016/j.jchromb.2016.09.004

R Core Team (2019). R: A Language and Environment for Statistical Computing. Vienna: R Foundation for Statistical Computing.

Dando, P. R., Southward, A. J., and Southward, E. C. (1986). Chemoautotrophic symbionts in the gills of the bivalve mollusc Lucinoma borealis and the sediment chemistry of its habitat. Proc. R. Soc. Lond. B 227, 227-247. doi: 10.1098/rspb. 1986.0021

Distel, D. L., Amin, M., Burgoyne, A., Linton, E., Mamangkey, G., Morrill, W., et al. (2011). Molecular phylogeny of Pholadoidea Lamarck, 1809 supports a single origin for xylotrophy (wood feeding) and xylotrophic bacterial endosymbiosis in Bivalvia. Mol. Phylogenet. Evol. 61, 245-254. doi: 10.1016/j.ympev.2011. 05.019

Distel, D. L., and Roberts, S. J. (1997). Bacterial endosymbionts in the gills of the deep-sea wood-boring bivalves Xylophaga atlantica and Xylophaga washingtona. Biol. Bull. 192, 253-261. doi: 10.2307/1542719

Dowle, M., and Srinivasan, A. (2019). Data.Table: Extension of 'Data.Frame'. R package version 1.12.6.

Fagervold, S. K., Romano, C., Kalenitchenko, D., Borowski, C., Nunes-Jorge, A., Martin, D., et al. (2014). Microbial communities in sunken wood are structured by wood-boring bivalves and location in a submarine canyon. PLoS One 9:e96248. doi: 10.1371/journal.pone.0096248

Ferrier-Pagés, C., and Leal, M. (2019). Stable isotopes as tracers of trophic interactions in marine mutualistic symbioses. Ecol. Evol. 9, 723-740. doi: 10. $1002 /$ ece 3.4712

Filipiak, M. (2018). "Nutrient dynamics in decomposing dead wood in the context of wood eater requirements: the ecological stoichiometry of saproxylophagous insects," in Saproxylic Insects. Zoological Monographs, Vol. 1, ed. M. Ulyshen, (Cham: Springer), 429-469. doi: 10.1007/978-3-319-75937-1_13

Filipiak, M., and Weiner, J. (2014). How to make a beetle out of wood: multielemental stoichiometry of wood decay, xylophagy and fungivory. PLoS One 9:e115104. doi: 10.1371/journal.pone.0115104

Gallager, S. M., Turner, R. D., and Berg, C. J. Jr. (1981). Physiological aspects of wood consumption, growth, and reproduction in the shipworm Lyrodus pedicellatus Quatrefages (Bivalvia: Teredinidae). J. Exp. Mar. Biol. Ecol. 52, 63-77. doi: 10.1016/0022-0981(81)90171-4

Gaudron, S. M., Haga, T., Wang, H., Laming, S. R., and Duperron, S. (2016). Plasticity in reproduction and nutrition in wood-boring bivalves (Xylophaga atlantica) from the Mid-Atlantic Ridge. Mar. Biol. 163:213. doi: 10.1007/ s00227-016-2988-6

González-Bergonzoni, I., Vidal, N., Wang, B., Ning, D., Liu, Z., Jeppesen, E., et al. (2015). General validation of formalin-preserved fish samples in food web studies using stable isotopes. Methods Ecol. Evol. 6, 307-314. doi: 10.1111/2041210x. 12313

Johnston, A., Hochcahka, W. M., Strimas-Mackey, M. E., Ruiz Gutierrez, V., Robinson, O. J., Miller, E. T., et al. (2019). Best practices for making reliable inferences from citizen science data: a case study using eBird to estimate species distributions. bioRxiv [Preprint]. doi: 10.1101/574392

Judge, J., and Barry, J. P. (2016). Macroinvertebrate community assembly on deepsea wood falls in Monterey Bay is strongly influenced by wood type. Ecology 97, 3031-3043. doi: 10.1002/ecy.1546

Kaehler, S., and Pakhomov, E. A. (2001). Effects of storage and preservation on the $\delta^{13} \mathrm{C}$ and $\delta^{15} \mathrm{~N}$ signatures of selected marine organisms. Mar. Ecol. Prog. Ser. 219, 299-304. doi: 10.3354/meps219299

Kalenitchenko, D., Péru, E., Pereira, L. C., Petetin, C., Galand, P. E., and LeBris, N. (2018). The early conversion of deep-sea wood falls into chemosynthetic hotspots revealed by in situ monitoring. Sci. Rep. 8:907. doi: 10.1038/s41598017-17463-2

Karande, A. A., Balasubramanian, K., and Prema, S. (1968). "Development of a laboratory method for bioassay of candidate toxins against teredid woodborers," in Proceedings of the Symposium on Molluscs, Part 111, (Mandapam: Marine Biological Association of India), 736-745.
Khripounoff, A., Vangriesheim, A., and Crassous, P. (1998). Vertical and temporal variations of particle fluxes in the deep tropical Atlantic. Deep Sea Res. 45, 193-216. doi: 10.1016/s0967-0637(97)00104-0

Korol, R. L., Kirschbaum, M. U. F., Farquhar, G. D., and Jeffreys, M. (1999). Effects of water status and soil fertility on the $\mathrm{C}$-isotope signature in Pinus radiata. Tree Physiol. 19, 551-562. doi: 10.1093/treephys/19.9.551

Lazier, E. L. (1924). Morphology of the Digestive Tract of Teredo navalis, Vol. 22. Berkeley, CA: University of California Publications in Zoology, 455-474. doi: 10.1093/treephys/19.9.551

Leavitt, S. W., and Long, A. (1986). Stable-carbon isotope variability in tree foliage and wood. Ecology 67, 1002-1010. doi: 10.2307/1939823

Loader, N. J., Robertson, I., and McCarroll, D. (2003). Comparison of stable carbon isotope ratios in the whole wood, cellulose and lignin of oak tree-rings. Palaeogeogr. Palaeoclimatol. Palaeoecol. 196, 395-407. doi: 10.1016/s00310182(03)00466-8

McClain, C., and Barry, J. (2014). Beta-diversity on deep-sea wood falls reflects gradients in energy availability. Biol. Lett. 10:20140129. doi: 10.1098/rsbl.2014. 0129

Minagawa, M., and Wada, E. (1984). Stepwise enrichment of $15 \mathrm{~N}$ along food chains: further evidence and the relation between $\delta 15 \mathrm{~N}$ and animal age. Geochim. Cosmochim. Acta 48, 1135-1140. doi: 10.1016/0016-7037(84)90204-7

Montoya, J. P., Carpenter, E. J., and Capone, D. G. (2002). Nitrogen fixation and nitrogen isotope abundances in zooplankton of the oligotrophic North Atlantic. Limnol. Oceanogr. 47, 1617-1628. doi: 10.1371/journal.pone.0131258

Muraoka, J. (1967). Deep-ocean biodeterioration of materials - Part VI. One year at 2370 feet. Naval Facilities Engineering Command. Port Hueneme, CA: U.S. Naval Civil Engineering Lab, 1-57.

Nishimoto, A., Mito, S., and Shirayama, Y. (2009). Organic carbon and nitrogen source of sunken wood communities on continental shelves around Japan inferred from stable isotope ratios. Deep Sea Res. II 56, 1683-1688. doi: 10. 1016/j.dsr2.2009.05.032

Ogawa, N. O., Koitabashi, T., Oda, H., Nakamura, T., Ohkouchi, N., and Wada, E. (2001). Fluctuations of nitrogen isotope ratio of gobiid fish (Isaza) specimens and sediments in Lake Biwa. Japan, during the 20th century. Limn. Oceanogr. 46, 1228-1236. doi: 10.4319/lo.2001.46.5.1228

Paalvast, P., and van der Velde, G. (2013). What is the main food source of the shipworm (Teredo navalis)? A stable isotope approach. J. Sea Res. 80, 58-60. doi: 10.1016/j.seares.2013.03.003

Page, H. M., Fisher, C. R., and Childress, J. J. (1990). Role of filter-feeding in the nutritional biology of a deep-sea mussel with methanotrophic symbionts. Mar. Biol. 104, 251-257. doi: 10.1007/bf01313266

Parzanini, C., Parrish, C. C., Hamel, J.-F., and Mercier, A. (2019). Reviews and syntheses: insights into deep-sea food webs and global environmental gradients revealed by stable isotope $\left(\delta^{15} \mathrm{~N}, \delta^{13} \mathrm{C}\right)$ and fatty acid trophic biomarkers. Biogeosciences 16, 2837-2856. https://doi.org/doi: 10.5194/bg-16-2837-2019, doi: 10.5194/bg-16-2837-2019

Pechenik, J. A., Perron, E. F., and Turner, R. D. (1979). The role of phytoplankton in the diets of adult and larval shipworms, Lyrodus pedicellatus (Bivalvia: Teredinidae). Estuar. Coasts 2, 58-60.

Purchon, R. D. (1941). On the biology and relationships of the lamellibranch Xylophaga dorsalis (Turton). J. Mar. Biol. Assoc. U. K. 45, 1-39. doi: 10.1017/ s0025315400014259

Rennie, M. D., Ozersky, T., and Evans, D. O. (2012). Effects of formalin preservation on invertebrate stable isotope values over decadal time scales. Can. J. Zool. 90, 1320-1327. doi: 10.1139/z2012-101

Revell, L. J. (2012). Phytools: an R package for phylogenetic comparative biology (and other things). Methods Ecol. Evol. 3, 217-223. doi: 10.1111/j.2041-210X. 2011.00169.x

Roeselers, G., and Newton, I. L. G. (2012). On the evolutionary ecology of symbioses between chemosynthetic bacteria and bivalves. Appl. Microbiol. Biotechnol. 94, 1-10. doi: 10.1007/s00253-011-3819-9

Romano, C., Pérez-Portela, R., and Martin, D. (2014). Morphological and genetic diversity of the wood-boring Xylophaga (Mollusca, Bivalvia): new species and records from deep-sea Iberian canyons. Plos One 9:e102887. doi: 10.1371/ journal.pone.0102887

Sabbadin, F., Pesante, G., Elias, L., Besser, K., Li, Y., Steele-King, C., et al. (2018). Uncovering the molecular mechanisms of lignocellulose digestion in shipworms. Biotechnol. Biofuels 11:59. doi: 10.1186/s13068-018-1058-3 
Sarakinos, H. C., Johnson, M. L., and Zanden, M. J. V. (2002). A synthesis of tissuepreservation effects on carbon and nitrogen stable isotope signatures. Can. J. Zool. 80, 381-387. doi: 10.1002/rcm.5049

Saraswathy, M., and Nair, N. B. (1971). XIV.-Observations on the structure of the shipworms, Nausitora hedleyi, Teredo furcifera and Teredora princesae (Bivalvia: Teredinidae). Trans. R. Soc. Edinb. 68, 507-566. doi: 10.1017/ s0080456800014861

Sarris, D., Siegwolf, R., and Körner, C. (2013). Inter- and intra-annual stable carbon and oxygen isotope signals in response to drought in Mediterranean pines. Agric. For. Meteorol. 168, 59-68. doi: 10.1016/j.agrformet.2012. 08.007

Schleser, G. H., Anhuf, D., Helle, G., and Vos, H. (2015). A remarkable relationship of the stable carbon isotopic compositions of wood and cellulose in tree-rings of the tropical species Cariniana micrantha (Ducke) from Brazil. Chem. Geol. 401, 59-66. doi: 10.1016/j.chemgeo.2015.02.014

Sigman, D. M., and Casciotti, K. L. (2001). "Nitrogen isotopes in the ocean," in Encyclopedia of Ocean Sciences, eds J. Steele, S. Thorpe, and K. Turekian, (Oxford: Academic Press), 4139-4152.

Silberberger, M. J., Renaud, P. E., Buhl-Mortensen, L., Ellingsen, I. H., and Reiss, H. (2019). Spatial patterns in sub-Arctic benthos: multiscale analysis reveals structural differences between community components. Ecol. Monogr. 89:e01325. doi: 10.1002/ecm.1325

Somes, C. J., Schmittner, A., and Altabet, M. A. (2010). Nitrogen isotope simulations show the importance of atmospheric iron deposition for nitrogen fixation across the Pacific ocean. Geophys. Res. Lett. 37:L23605. doi: 10.1029/ 2010GL044537

Syväranta, J., Martino, A., Kopp, D., Céréghino, R., and Santoul, F. (2011). Freezing and chemical preservatives alter the stable isotope values of carbon and nitrogen of the Asiatic clam (Corbicula fluminea). Hydrobiologia 658, 383-388. doi: 10.1007/s10750-010-0512-4

Syväranta, J., Vesala, S., Rask, M., Ruuhijärvi, J., and Jones, R. I. (2008). Evaluating the utility of stable isotope analyses of archived freshwater sample material. Hydrobiologia 600, 121-130. doi: 10.1007/s10750-0079181-3

Taylor, A. M., Brooks, J. R., Lachenbruch, B., and Morrell, J. J. (2007). Radial patterns of carbon isotopes in the xylem extractives and cellulose of Douglas-fir. Tree Physiol. 27, 921-927. doi: 10.1093/treephys/27.6.921

Thieltges, D. W., Goedknegt, M. A., O’Dwyer, K., Senior, A. M., and Kamiya, T. (2019). Parasites and stable isotopes: a comparative analysis of isotopic discrimination in parasitic trophic interactions. Oikos 128, 1329-1339. doi: 10.1111/oik.06086We

Turner, R. D. (1955). The family Pholadidae in the western Atlantic and the eastern Pacific II. Martesiinae, Jouannetinae and Xylophaginae. Johnsonia 3, 65-160.

Turner, R. D. (1966). A Survey and Illustrated Catalogue of the Teredinidae. Cambridge, MA: Museum Comparative Zoology.

Turner, R. D. (1973). Wood-boring bivalves, opportunistic species in the deep sea. Science 180, 1377-1379. doi: 10.1126/science.180.4093.1377
Voight, J. R. (2007). Experimental deep-sea deployments reveal diverse Northeast Pacific wood-boring bivalves of Xylophagainae (Myoida: Pholadidae). J. Mollus. Stud. 73, 377-391. doi: 10.1093/mollus/eym034

Voight, J. R. (2008). Deep-sea wood-boring bivalves of Xylophaga (Myoida: Pholadidae) on the continental shelf. J. Mar. Biol. Assoc. U. K. 88, 1467-1472.

Voight, J. R. (2016). New insights on Xylopholas (Mollusca: Xylophagaidae): diversity, growth and reproduction. Am. Malacol. Bull. 34, 138-146. doi: 10. 4003/006.034.0210

Voight, J. R., Marshall, B. A., Judge, J., Halanych, K. M., Li, Y., Bernardino, A. F., et al. (2019). Life in wood: preliminary phylogeny of deep-sea wood-boring bivalves (Xylophagaidae), with descriptions of three new genera and one new species. J. Mollus. Stud. 85, 232-243. doi: 10.1093/mollus/eyz003

Voight, J. R., and Segonzac, M. (2012). At the bottom of the deep blue sea: a new wood-boring bivalve (Mollusca, Pholadidae, Xylophaga) from the Cape Verde Abyssal Plain (subtropical Atlantic). Zoosystema 34, 171-180. doi: 10. 5252/z2012n1a8

Web, H. L. (1900). The problems of a Pacific cable. Scribn. Mag. 27, 229-236.

Wickham, H. (2016). Ggplot2: Elegant Graphics for Data Analysis. New York, NY: Springer.

Wickham, H. (2017). tidyverse: Easily Install and Load the 'Tidyverse'. R package version 1.2.1.

Wright, M., and Ziegler, A. (2017). Ranger: a fast implementation of random forests for high dimensional data in $\mathrm{C}++$ and R. J. Stat. Softw.77, 1-7. doi: 10.18637/jss.v077.i01

Yamanaka, T., Shimamura, S., Chikaraishi, Y., Haga, T., and Fujiwara, Y. (2015). Re-evaluation of nutrient sources for deep-sea wood-boring bivalves using the isotopic composition of bulk C, N, S, and amino acid nitrogen. Mar. Ecol. Prog. Ser. 540, 157-165. doi: 10.3354/meps 11510

Zapata-Hernández, G., Sellanes, J., Thiel, M., Henríquez, C., Hernández, S., Fernández, J. C. C., et al. (2016). Community structure and trophic ecology of megabenthic fauna from the deep basins in the interior sea of Chiloé, Chile (41-43 ${ }^{\circ}$ S). Cont. Shelf Res. 130, 47-67. doi: 10.1016/j.csr.2016. 10.002

Zar, J. H. (1999). Biostatistical Analysis, 4th Edn. Upper saddle River, NJ: Prentice Hall.

Conflict of Interest: The authors declare that the research was conducted in the absence of any commercial or financial relationships that could be construed as a potential conflict of interest.

Copyright (c) 2020 Voight, Cooper and Lee. This is an open-access article distributed under the terms of the Creative Commons Attribution License (CC BY). The use, distribution or reproduction in other forums is permitted, provided the original author(s) and the copyright owner(s) are credited and that the original publication in this journal is cited, in accordance with accepted academic practice. No use, distribution or reproduction is permitted which does not comply with these terms. 